\title{
PENGARUH PROFITABILITAS, LIKUIDITAS, FINANCIAL LEVERAGE, DAN STRUKTUR KEPEMILIKAN TERHADAP KETEPATAN WAKTU PELAPORAN KEUANGAN PADA PERUSAHAAN MANUFAKTUR YANG TERDAFTAR DI BURSA EFEK INDONESIA PADA TAHUN 2013-2015
}

\author{
Dimas Aldrian Diliasmara*1, Nadirsyah ${ }^{* 2}$ \\ 1,2Program Studi Akuntansi Fakultas Ekonomi dan Bisnis Universitas Syiah Kuala \\ e-mail: aldrian.dimas@gmail.com ${ }^{* 1}$, nadirsyah1964@gmail.com ${ }^{* 2}$
}

\begin{abstract}
Abstrak
Penelitian ini bertujuan untuk mengetahui pengaruh profitabilitas, likuiditas, financial leverage, dan struktur kepemilikan terhadap ketepatan waktu pelaporan keuangan perusahaan manufaktur di Bursa Efek Indonesia (BEI) secara bersama-sama dan parsial. Dalam penelitian ini profitabilitas diukur dengan menggunakan Return on Assets, likuiditas diukur dengan Current Assets, financial leverage diukur dengan Debt to Equity Ratio, stuktur kepemilikan diukur dengan menggunakan proksi kepemilikan pihak luar yang dihitung dengan persentase kepemilikan pihak luar terbesar perusahaan. Data variabel independen diperoleh dari laporan keuangan tahunan perusahaan manufaktur yang terdaftar di BEI, sedangkan data variabel dependen diperoleh dari The Indonesia Capital Market Institute (TICMI). Periode penelitian yang digunakan adalah 3 tahun yaitu tahun 2013-2015. Dengan metode purposive sampling sehingga total ada 264 perusahaan yang memenuhi kriteria sampel. Regresi logistik digunakan untuk menguji hipotesis. Hasil penelitian menunjukkan bahwa profitabilitas, likuiditas, financial leverage, dan struktur kepemilikan berpengaruh secara bersama-sama terhadap ketepatan waktu pelaporan keuangan. Likuiditas dan financial leverage tidak berpengaruh terhadap ketepatan waktu pelaporan keuangan secara parsial. Profitabilitas dan stuktur kepemilikan berpengaruh signifikan terhadap ketepatan waktu pelaporan keuangan.
\end{abstract}

Keywords: profitabilitas, likuiditas, financial leverage, struktur kepemilikan, dan ketepatan waktu pelaporan keuangan.

\section{Pendahuluan}

Laporan keuangan merupakan akhir dari proses akuntansi yang mempunyai peranan penting bagi pengukuran serta penilaian kerja suatu perusahaan. Menurut Pernyataan Standar Akuntansi Keuangan (PSAK) 1, laporan keuangan mempunyai tujuan untuk memberikan informasi tentang posisi keuangan, kinerja, dan arus kas perusahaan yang bermanfaat bagi kalangan pengguna laporan dalam rangka membuat keputusan-keputusan ekonomi serta menunjukkan pertanggungjawaban (stewardship) manajemen atas penggunaan sumber daya yang dipercayakan kepada mereka (IAI, 2014).

Perusahaan di Indonesia sendiri terbagi dalam dua jenis, yaitu perusahaan yang masih menggunakan modal sendiri dan perusahaan yang sudah go public sudah melakukan IPO (Initial Public Offering) di Bursa Efek Indonesia (BEI). Perusahaan yang sudah go public diharuskan menyusun laporan keuangan setiap periodenya. Laporan keuangan yang dikeluarkan oleh perusahaan-perusahaan yang telah go public akan digunakan oleh investor untuk dapat memantau kondisi perusahaan. Selain menggunakan laporan keuangan, investor juga memperhatikan ketepatan waktu perusahaan dalam mempublikasikan laporan keuangannya sebagai pertimbangan dalam berinvestasi di pasar modal.

Informasi pada laporan keuangan dikatakan relevan jika informasi tersebut disampaikan tepat waktu dan memiliki manfaat bagi penggunanya. Keterlambatan dalam penyelesaian penyajian laporan keuangan dapat memberikan dampak yang positif maupun negatif mengenai informasi yang terkandung dalam laporan keuangan. Faktor-faktor tersebut tidak hanya terbatas pada faktor finansial saja tetapi juga faktor non-finansial (Almilia dan Setiady, 2006).

Kewajiban penyampaian laporan keuangan perusahaan publik diatur dalam UU No. 8 tahun 1995 
tentang Pasar Modal dan Keputusan Ketua Badan Pengawas Pasar Modal (Bapepam) dan Lembaga Keuangan (LK) yang menyatakan bahwa suatu emiten harus (diwajibkan) menyampaikan laporan keuangan secara berkala (akhir tahunan dan tengah tahunan) yang disusun berdasarkan Pernyataan Standar Akuntansi Keuangan (PSAK) yang menyatakan laporan keuangan tahunan wajib disertai dengan pendapat akuntan publik dan selambat-lambatnya 120 hari (akhir bulan keempat) setelah tanggal akhir tahun tutup buku perusahaan.

Meskipun telah adanya kebijakan mengenai batas akhir penyampaian laporan keuangan tahunan, namun masih ada emiten-emiten yang terlambat dalam penyampaian laporan keuangan tahunannya. Data yang didapat dari The Indonesia Capital Market Institute (TICMI) menunjukkan daftar perusahaan yang terlambat melaporkan laporan keuangannya tahun 2013-2015.

Data tersebut menunjukkan perbedaan jumlah perusahaan yang tepat waktu dan yang terlambat dalam menyampaikan laporan keuangannya. Pada tahun 2013 sebanyak 49 emiten terlambat menyampaikan Laporan Keuangan (LK) periode 2012 yang telah diaudit, sedangkan di tahun 2014 ada 52 emiten terlambat untuk LK periode 2013, dilanjutkan di tahun 2015 sebanyak 63 emiten yang terlambat menyampaikan LK periode 2014.

Dalam mempublikasikan laporan keuangannya, perusahaan cenderung akan memperlihatkan kondisi baik (window dressing) sehingga akan menarik perhatian investor untuk berinvestasi. Sebelum membuat keputusan untuk berinvestasi di pasar modal, investor perlu mengetahui kondisi perusahaan yang dituju, terutama kondisi keuangannya. Untuk menganalisis kondisi keuangan perusahaan, dapat melalui beberapa rasio keuangan, yaitu rasio profitabilitas, rasio likuiditas, dan rasio leverage.

Menurut Respati (2004), profitabilitas menunjukkan keberhasilan perusahaan dalam menghasilkan keuntungan sehingga dapat dikatakan bahwa profit merupakan berita baik (good news) bagi perusahaan. Semakin besar tingkat profit yang dihasilkan maka semakin baik pula kinerja perusahaan sehingga dalam menyampaikan informasi laporan keuangan cenderung lebih tepat waktu, karena tingginya tingkat profit merupakan berita baik bagi perusahaan.
Pengelolaan utang juga akan mempengaruhi good news dan bad news dalam laporan keuangan yang akan dipublikasikan. Likuiditas mengacu pada kemampuan perusahaan dalam memenuhi kewajiban jangka pendeknya yang jatuh tempo secara tepat waktu. Peningkatan jumlah utang akan menyebabkan perusahaan lebih cepat dalam menyampaikanlaporan keuangan tahunan yang telah diaudit. Oleh karena itu perusahaan yang mempunyai komposisi utang yang lebih tinggi wajib memenuhi kebutuhan informasi yang cukup kepada investor (Abdullah dalam Wirakusuma, 2004).

Selain likuiditas, penggunaan utang dalam usaha juga menjadi aspek dimana perusahaan akan menunjukkan kualitasnya dalam mengelola utangutang yang ada. Dalam manajemen keuangan, utang digunakan untuk meningkatkan kinerja perusahaan. Jika perusahaan hanya mengandalkan modal dan ekuitasnya saja, perusahaan akan sulit melakukan ekspansi bisnis sehingga membutuhkan modal tambahan. Namun jika jumlah utang sudah melebihi jumlah ekuitas yang dimiliki oleh perusahaan, risiko dari sisi likuiditas juga akan tinggi sehingga dapat menyebabkan perusahaan mengalami kerugian yang nantinya akan menjadi faktor perusahaan untuk menunda penyampaian pelaporan keuangannya.

Adanya struktur kepemilikan pihak dalam dan luar perusahaan akan menimbulkan pengaruh pada kinerja perusahaan karena adanya rasa memiliki perusahaan sehingga pihak manajemen akan semakin baik. Apabila kinerja manajemen dapat memuaskan pihak luar yaitu pemegang saham, maka kinerja manajemen dikatakan baik dan begitu juga sebaliknya. Upaya manajemen untuk menunjukkan kinerja yang baik adalah dengan menyediakan informasi mengenai posisi keuangan, kinerja perusahaan, dan perubahaan posisi keuangan bagi pemilik dari pihak luar. Pemilik perusahaan dari pihak luar mempunyai kekuatan yang besar untuk menekan manajemen dalam menyajikan informasi secara tepat waktu, karena ketepatan waktu pelaporan keuangan akan mempengaruhi pengambilan keputusan ekonomi (Saleh, 2004).

Penelitian dengan fokus profitabilitas, likuiditas dan leverage pernah dilakukan oleh Hilmi dan Ali (2008) dengan sampel perusahaan manufaktur di BEI tahun 2004-2006. Hasil penelitian menyatakan profitabilitas dan likuiditas berpengaruh secara signifikan terhadap ketepatan waktu penyampaian 
laporan keuangan, sedangkan leverage tidak berpengaruh. Penelitian yang dilakukan oleh Mufqi (2015) memiliki fokus leverage, profitabilitas dan kepemilikan pihak luar dengan populasi perusahaan makanan dan minuman yang terdaftar di BEI tahun 2012-2013. Hasil penelitian tersebut menyatakan bahwa dalam hubungannya, leverage dan profitabilitas memiliki pengaruh yang signifikan dengan ketepatan waktu perusahaan menyampaikan laporan keuangannnya, sedangkan kepemilikan pihak luar tidak ditemukan pengaruh yang signifikan. Berdasarkan uraian penelitian tersebut, peneliti tertarik untuk melakukan penelitian lanjutan yang termotivasi oleh penelitian Hilmi dan Ali (2008), dan Mufqi (2015).

Berdasarkan fenomena tersebut, penelitian bermaksud menjadi pengembangan dari penelitian yang pernah dilakukan oleh Hilmi dan Ali (2008) dan Mufqi (2015), yaitu menggunakan data laporan keuangan manufaktur yang terdaftar di BEI tahun 2013 - 2015 dengan empat jenis variabel independen, yaitu profitabilitas, likuiditas, financial leverage, dan struktur kepemilikan dalam proksi kepemilikan pihak luar. Penggunaan satu jenis kelompok industri manufaktur bertujuan untuk menghindari perbedaan karakteristik antara perusahaan manufaktur dan non manufaktur. Tujuan lainnya dalam penggunaan kelompok industri manufaktur dikarenakan sebagian besar perusahaan di Indonesia adalah perusahaan yang bergerak dalam bidang manufaktur sehingga peneliti tertarik dengan data yang digunakan akan relevan dan menarik untuk dapat ditarik kesimpulan. Karena itu peneliti ingin meneliti lebih lanjut dengan judul penelitian, "Pengaruh Profitabilitas, Likuiditas, Financial Leverage, dan Struktur Kepemilikan Terhadap Ketepatan Waktu Pelaporan Keuangan Pada Perusahaan Manufaktur Yang Terdaftar di Bursa Efek Indonesia Tahun 2013-2015".

\section{Tinjauan Literatur, Kerangka Pemikiran, dan Hipotesis}

\section{Tinjauan Literatur}

\section{Teori Keagenan (Agency Theory)}

Jensen dan Meckling (2005) menjelaskan teori keagenan (agency theory) sebagai hubungan kontrak antara satu orang atau lebih yang melibatkan orang lain untuk melakukan beberapa layanan atau kegiatan atas nama mereka yang mendelegasikan wewenang untuk pengambilan keputusan. Terdapat dua pelaku yang saling berhubungan yaitu prinsipal dan agen, dimana prinsipal atau pemilik adalah pihak yang melakukan evaluasi terhadap informasi dan agen sebagai pihak yang menjalankan kegiatan manajemen dan mengambil keputusan.

Teori keagenan juga menjelaskan mengenai adanya asimetri informasi (information asymmetry) antara manajer sebagai agen dan pemilik (pemegang saham) sebagai prinsipal yang merupakan kondisi di mana prinsipal sebagai pemilik tidak mempunyai informasi yang mencukupi mengenai kinerja agen dalam menjalankan dan pengambilan keputusan sehingga tidak mengetahui pasti bagaimana usaha agen dalam memberikan kontribusi pada hasil aktual perusahaan. Agen yang secara langsung berhubungan dengan proses perusahaan mendapatkan informasi yang lebih banyak dibandingkan prinsipal, hal ini dikarenakan prinsipal tidak mengetahui informasi tentang kinerja perusahaan secara langsung melainkan melalui agen.

Untuk memperkecil asimetri informasi, maka pengelolaan perusahaan harus diawasi dan dikendalikan untuk memastikan bahwa pengelolaan dilakukan dengan penuh kepatuhan kepada berbagai peraturan dan ketentuan yang berlaku. Kadir (2008) menyatakan bahwa laporan keuangan yang disampaikan dengan segera atau tepat waktu akan dapat mengurangi asimetri informasi tersebut.

\section{Ketepatan Waktu Pelaporan Keuangan}

Pernyataan Standar Akuntansi Keuangan (PSAK) 1 tentang Penyajian Laporan Keuangan, menyebutkan terdapat empat karakteristik kualitatif laporan keuangan yang dapat berguna bagi para pemakainya (IAI, 2014). Keempat karakteristik kualitatif informasi tersebut menurut IAI (2014) adalah:

\section{Dapat dipahami (Understandability)}

Kualitas penting dalam laporan keuangan adalah kemudahan untuk dapat dipahami oleh pemakai. Dalam hal ini, pemakai diasumsikan memiliki pengetahuan yang memadai tentang aktivitas ekonomi dan bisnis, akuntansi, serta kemauan untuk mempelajari dengan ketekunan yang wajar. 


\section{Relevan (Relevance)}

Suatu laporan keuangan dikatakan relevan apabila informasi yang disajikan dalam laporan keuangan tersebut memiliki manfaat sesuai dengan tindakan yang akan dilakukan oleh pemakai laporan keuangan. Dengan kata lain, relevan merupakan kemampuan suatu informasi untuk mempengaruhi keputusan manajer atau pemakai laporan keuangan lainnya sehingga keberadaan informasi tersebut mampu mengubah atau mendukung harapan mereka tentang hasilhasil atau konsekuensi dari tindakan yang diambil.

3. Keandalan (Reliability)

Keandalan merupakan kualitas informasi yang disampaikan laporan keuangan menyebabkan pemakai informasi akuntansi sangat tergantung pada kebenaran informasi yang dihasilkan. Keandalan suatu informasi sangat tergantung pada kemampuan suatu informasi untuk menggambarkan secara wajar keadaan/peristiwa yang digambarkan sesuai dengan kondisi yang sebenarnya.

4. Dapat diperbandingkan (Comparability)

Suatu laporan keuangan dapat diperbandingkan bila informasi tersebut dapat saling diperbandingkan baik antarperiode maupun antarperusahaan sehingga pemakai dapat memperoleh informasi tentang kebijakan akuntansi yang digunakan dalam penyusunan laporan keuangan dan perubahan kebijakan serta pengaruh dari perubahan tersebut.

Hilmi dan Ali (2008) juga mengungkapkan ketepatan waktu (timeliness) merupakan salah satu faktor penting dalam menyajikan suatu informasi yang relevan. Karakteristik informasi yang relevan harus mempunyai nilai prediktif dan disajikan tepat waktu. Laporan keuangan sebagai sebuah informasi akan bermanfaat apabila informasi yang dikandungnya disediakan tepat waktu bagi pembuat keputusan sebelum informasi tersebut kehilangan kemampuannya dalam mempengaruhi pengambilan keputusan. Jika terdapat penundaan yang tidak semestinya dalam pelaporan, informasi yang dihasilkan akan kehilangan relevansinya.

Chambers dan Penman (1984) mendefinisikan ketepatan waktu dalam dua cara yaitu, ketepatan waktu yang didefinisikan sebagai keterlambatan waktu pelaporan dari tanggal laporan keuangan sampai tanggal melaporkan, dan ketepatan waktu yang ditentukan dengan ketepatan waktu pelaporan relatif atas tanggal pelaporan yang diharapkan.

Dyer dan Mc Hugh (1975) menggunakan tiga kriteria keterlambatan untuk melihat ketepatwaktuan penyampaian laporan keuangan, yaitu:

1. Preliminary lag yaitu interval jumlah hari antara tanggal laporan keuangan sampai penerimaan laporan akhir preleminary oleh bursa.

2. Auditor's report lag yaitu interval jumlah hari antara tanggal laporan keuangan sampai tanggal laporan auditor ditandatangani.

3. Total lag yaitu interval jumlah hari antara tanggal laporan keuangan sampai tanggal penerimaan laporan dipublikasikan oleh bursa.

Penyampaian pelaporan keuangan bagi perusahaan publik diatur dalam UU No. 8 tahun 1995 tentang Pasar Modal. Peraturan Bapepam yang saat ini sudah melebur dalam lembaga Otoritas Jasa Keuangan (OJK) dimana aturannya telah diperbaharui pada tahun 2011 yakni Surat Keputusan Ketua Badan Pengawas Pasar Modal dan Lembaga Keuangan (LK) Nomor KEP- 346/BL/2011 pada tanggal 5 Juli 2011 tentang penyampaian laporan keuangan berkala emiten atau perusahaan publik dan peraturan I.E tentang kewajiban penyampaian informasi bahwa batas penyampaian laporan keuangan tahunan adalah selambat-lambatnya pada akhir bulan ke-3 (ketiga) atau 90 hari setelah tanggal laporan keuangan tahunan. Apabila perusahaan tidak menyampaikan laporan keuangannya secara tepat waktu maka akan dikenakan sanksi administratif.

\section{Profitabilitas}

Profitabilitas adalah kemampuan perusahaan untuk menghasilkan keuntungan dalam suatu periode waktu tertentu. Profitabilitas merupakan salah satu indikator keberhasilan perusahaan untuk dapat menghasilkan laba sehingga semakin tinggi profitabilitas maka semakin tinggi kemampuan perusahaan untuk menghasilkan laba bagi perusahaannya (Hilmi dan Ali, 2008).

Menurut Givoly dan Palmon (1982), perusahaan yang memperoleh laba cenderung menyampaikan laporan keuangannya secara tepat waktu, sebaliknya perusahaan yang mengalami 
kerugian cenderung tidak tepat waktu dalam menyampaikan laporan keuangannya. Carslaw dan Kaplan (1991) menyatakan bahwa perusahaan yang mengalami rugi cenderung memerlukan auditor untuk memulai proses pengauditan lebih lambat dari biasanya. Oleh karena hal tersebut, maka akan terjadi pula keterlambatan dalam menyampaikan kabar buruk kepada publik.

Basuony (2016) dalam penelitiannya menyatakan profitabilitas perusahaan dapat dianggap sebagai indikator manajemen yang baik sehingga perusahaan yang mengalami keuntungan dapat meyakinkan auditornya untuk menerbitkan laporan mereka dalam waktu yang lebih singkat agar dapat menyampaikan kabar baik kepada pemegang saham mengenai keuntungan yang dibuat. Hasil ROA yang negatif disebabkan laba perusahaan dalam kondisi negatif atau mengalami kerugian. Artinya modal yang diinvestasikan secara keseluruhan belum mampu untuk menghasilkan laba. Penggunaan ROA sebagai rasio profitabilitas dalam penelitian ini lebih baik daripada rasio profitabilitas lainnya karena pengukuran ROA yang komparatif dan mempengaruhi laporan keuangan.

\section{Likuiditas}

Likuiditas adalah bagaimana perusahaan mengukur kemampuan perusahaan untuk memenuhi kewajiban jangka pendek yang dimiliki oleh perusahaan (Hanafi 2003:77). Likuiditas perusahaan menunjukkan kemampuan suatu perusahaan untuk membayar kewajiban finansial jangka pendek tepat pada waktunya. Likuiditas perusahaan dapat ditunjukkan oleh besar kecilnya aset lancar yaitu aset yang mudah untuk diubah menjadi kas yang meliputi kas, surat berharga, piutang, dan persediaan.

Tingkat likuiditas yang tinggi pada sebuah perusahaan menunjukkan bahwa perusahaan tersebut dapat memenuhi kewajiban jangka pendeknya dengan baik, sedangkan tingkat likuiditas yang rendah menunjukkan bahwa perusahaan tidak dapat memenuhi kewajiban jangka pendeknya dengan baik. Likuiditas suatu perusahaan sering ditunjukkan oleh rasio lancar, yaitu perbandingan aset lancar dengan kewajiban lancar. Rasio ini dapat memberikan sebuah ukuran likuiditas yang cepat, mudah digunakan dan mampu menjadi indikator terbaik dari sampai sejauh mana klaim dari kreditor jangka pendek telah ditutupi oleh aset yang diharapkan dapat diubah menjadi kas dengan cukup cepat (Brigham dan Houston, 2006).

Apabila perbandingan aset lancar dengan hutang lancar semakin besar, artinya semakin tinggi kemampuan perusahaan dalam menutupi kewajiban jangka pendeknya. Perusahaan yang mempunyai tingkat likuiditas yang tinggi menunjukkan kabar baik (good news) bagi perusahaan yang nantinya akan mempengaruhi perusahaan untuk menyampaikan laporan keuangannya dengan tepat waktu karena akan membuat reaksi pasar menjadi positif terhadap perusahaan (Nasution, 2013).

\section{Financial Leverage}

Rasio-rasio keuangan memperlihatkan
gambaran kondisi perusahaan dalam bidang
keuangan. Jika perusahaan sedang dalam kondisi
yang tidak baik maka pihak manajemen biasanya
berusaha untuk menutupi berita buruk tersebut
(Toding dan Wirakusuma, 2013).

Srimindarti (2008) menjelaskan bahwa leverage ratio adalah rasio yang digunakan untuk mengukur kemampuan perusahaan dalam membayar hutang apabila perusahaan dilikuidasi atau dibubarkan. Rasio ini menunjukkan seberapa jauh perusahaan dibiayai oleh pihak luar atau kreditur. Salah satu rasio leverage adalah Debt to Equity Ratio (DER). DER digunakan untuk mengukur tingkat leverage (penggunaan hutang) terhadap total shareholder's equity yang dimiliki perusahaan.

Dikatakan bahwa perusahaan dengan rasio hutang yang tinggi dianggap berisiko jauh lebih tinggi oleh pemberi pinjaman. Risiko perusahaan yang tinggi mengindikasikan bahwa perusahaan mengalami kesulitan keuangan. Kesulitan keuangan perusahaan merupakan berita buruk yang akan mempengaruhi kondisi perusahaan di pandangan publik. Pihak manajemen cenderung akan menunda penyampaian laporan keuangan yang berisi berita buruk. Perusahaan dengan kondisi DER yang tinggi akan terlambat dalam penyampaian pelaporan keuangannya, karena waktu yang ada akan 
digunakan untuk menekan DER serendahrendahnya (Khasharmeh, 2010).

Penelitian mengenai pengaruh DER terhadap ketepatan waktu dilakukan oleh Na'im (1998) yang menyatakan bahwa DER tidak signifikan berpengaruh terhadap ketepatan waktu pelaporan keuangan perusahaan. Berdasarkan ketidakkonsistenan hasil penelitian yang dilakukan sebelumnya, hipotesis sementara yang dapat diambil adalah DER secara signifikan berpengaruh terhadap ketepatan waktu pelaporan keuangan.

\section{Struktur Kepemilikan}

Struktur kepemilikan perusahaan yang go public dapat disebut sebagai kepemilikan terhadap saham perusahaan yang di dalam kepemilikan tersebut perlu mempertimbangkan dua aspek, yaitu kepemilikan oleh pihak dalam atau manajemen perusahaan (insider ownerships) dan kepemilikan oleh pihak luar (outsider ownerships) (Dwiyanti, 2010).

Respati (2004) menjelaskan kepemilikan perusahaan dari pihak luar mempunyai kekuatan yang besar dalam mempengaruhi perusahaan baik melalui media massa maupun kritikan atau komentar yang semuanya merupakan kekuatan publik atau masyarakat. Dengan adanya konsentrasi kepemilikan pihak luar maka akan mengubah pengelolaan menjadi perusahaan yang berjalan dengan pengawasan. Laporan keuangan yang tepat waktu membantu kepemilikan pihak luar untuk mempertahankan investasinya dengan memantau kinerja manajemen dan membuat keputusan yang efisien sesegera mungkin untuk perusahaan (Basuony, 2016).

Upaya pihak manajemen untuk menunjukkan kinerja yang baik adalah dengan memberikan informasi perkembangan dan kondisi perusahaan. Manajemen sebagai penyedia informasi dituntut untuk menyajikan informasi secara tepat waktu dan relevan. Struktur kepemilikan perusahaan yang dimiliki oleh pihak luar biasanya mempunyai persentase kepemilikan lebih dari 50 persen sehingga pemilik perusahaan dari pihak luar mempunyai kekuatan yang besar dalam mempengaruhi kondisi dan hasil kinerja perusahaan (Hastutik, 2015).

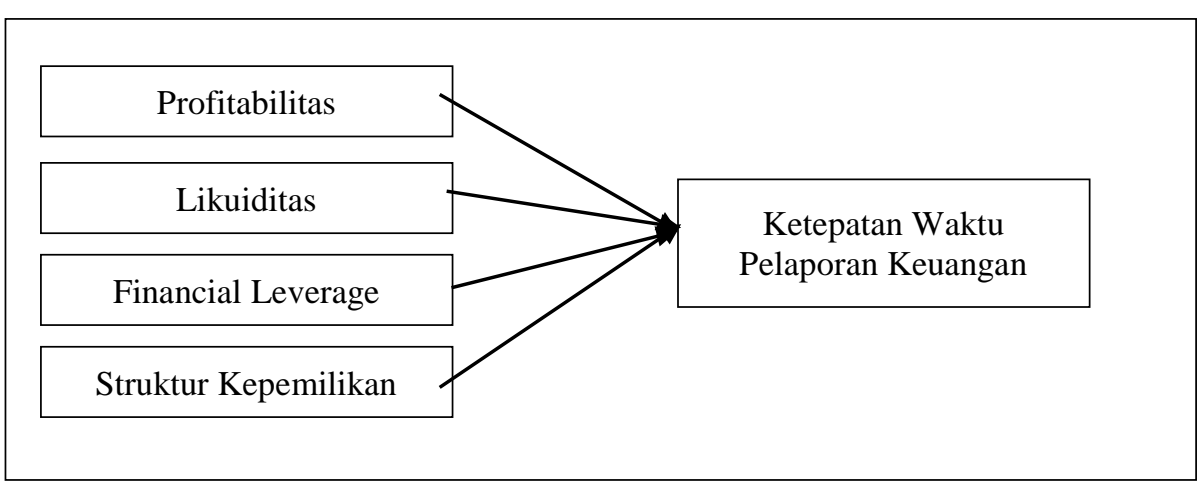

\section{Grafik 1.1 Kerangka Penelitian}

\section{Pengembangan Hipotesis}

Berdasarkan kerangka yang disebutkan diatas, hipotesis yang dapat diambil dari penelitian ini adalah profitabilitas, likuiditas, financial leverage, dan struktur kepemilikan secara bersama-sama berpengaruh terhadap ketepatan waktu pelaporan keuangan; profitabilitas berpengaruh terhadap ketepatan waktu pelaporan keuangan; likuiditas berpengaruh terhadap ketepatan waktu pelaporan keuangan; financial leverage berpengaruh terhadap ketepatan waktu pelaporan keuangan; dan struktur kepemilikan berpengaruh terhadap ketepatan waktu pelaporan keuangan.

\section{Metodologi Penelitian Populasi dan Sampel Penelitian}

Populasi yang digunakan dalam penelitian ini adalah perusahaan manufaktur yang tercatat di BEI (Bursa Efek Indonesia) dengan periode pengamatan penelitian dilakukan dari tahun 2013-2015. Dalam penelitian ini metode pemilihan sampel digunakan metode purposive sampling dengan kriteria-kriteria berikut:

1. Perusahaan Manufaktur yang telah listing di Bursa Efek Indonesia dan tidak pernah de-list selama periode 2013-2015. 
2. Perusahaan tersebut telah menerbitkan laporan keuangan tahunan yang dipublikasikan di BEI secara berturut-turut selama periode 2013-2015.

3. Perusahaan tersebut memakai mata uang Rupiah dalam laporan keuangan tahunannya.
4. Perusahaan yang memiliki laporan keuangan berakhir pada 31 Desember.

Tabel 1.1

Tabel Pemilihan Sampel

\begin{tabular}{|l|c|}
\hline \multicolumn{1}{|c|}{ Kriteria Sampel } & $\begin{array}{c}\text { Jumlah } \\
\text { Perusahaan }\end{array}$ \\
\hline Perusahaan manufaktur yang secara berturut-turut terdaftar di BEI selama tahun 2013-2015. & 136 \\
\hline Perusahaan manufaktur yang laporan keuangannya berakhir pada 31 Desember. & 127 \\
\hline Perusahaan manufaktur yang memakai mata uang Rupiah dalam laporan keuangan tahunannya & 88 \\
\hline Jumlah sampel perusahaan manufaktur tahun 2013-2015. (sampel per tahun x 3 tahun) & 264 \\
\hline
\end{tabular}

Sumber: Data diolah (2017)

\section{Teknik Pengumpulan Data}

Data yang digunakan dalam penelitian ini adalah data sekunder yang mengacu pada informasi yang dikumpulkan dari sumber yang ada. Data sekunder yaitu sumber data penelitian yang diperoleh secara tidak langsung melalui media perantara, baik yang dipublikasikan dan tidak dipublikasikan.

Data sekunder yang digunakan dalam penelitian ini adalah laporan tahunan (annual report) dan laporan keuangan (financial report) tahunan perusahaan manufaktur yang terdaftar di BEI tahun 2013-2015 dan data tanggal penyampaian laporan tersebut kepada BEI. Data diperoleh dari situs resmi Bursa Efek Indonesia (http://www.idx.co.id) dan The Indonesia Capital Market Institute (TICMI) (http://ticmi.co.id).

\section{Metode Analisis dan Rancangan Pengujian Hipotesis}

Untuk dapat melakukan analisis data, diperlukan pengujian kualitas data yang ada dengan menggunakan uji statistik deskriptif sehingga dapat menggambarkan variabel-variabel yang ada di dalam penelitian ini. Penelitian statistik deskriptif memberikan gambaran atau deskriptif suatu data yang dapat dilihat dari nilai rata-rata (mean), standar deviasi, varians, dan range statistik.

Pengujian hipotesis dalam penelitian ini dilakukan secara multivariate. Pengujian multivariate dilakukan dengan menggunakan regresi logistik. Model ini dipilih karena data di dalam penelitian ini adalah berupa data nominal dan rasio (Ghozali: 2013:225).
Variabel dependen yang berupa data nominal dan independen berupa data rasio membuat regresi logistik merupakan yang paling tepat digunakan. Dengan menggunakan regresi logistik, maka tidak diperlukannya lagi pengujian dengan uji asumsi klasik dan uji normalitas pada variabel bebasnya. Pengolahan data dalam penelitian ini menggunakan program SPSS (Statistical Package For Social Science) 22. Model regresi logistik yang digunakan dalam penelitian ini adalah sebagai berikut:

$$
\begin{gathered}
\ln (\mathrm{TL} / 1-\mathrm{TL})=\alpha+\beta_{1} \mathrm{ROA}+\beta_{2} \mathrm{CR}+\beta_{3} \mathrm{DER}+\beta \\
{ }_{4} \text { OUTCON }+\varepsilon
\end{gathered}
$$

Keterangan:

$\ln (\mathrm{TL} / 1-\mathrm{TL}): \quad$ Simbol yang menunjukkan probabilitas ketepatan waktu penyampaian laporan keuangan

$\alpha \quad$ : Konstanta

$\beta_{\text {I }} \quad:$ Koefisien Regresi

ROA : Profitabilitas (Return on Asset)

CR : Likuiditas (Current Ratio)

DER : Financial Leverage (Debt to Equity Ratio)

OUTCON : Presentase kepemilikan pihak luar (Outsider Ownership Concentration)

$\varepsilon \quad$ : Error terms

\section{Hasil dan Pembahasan \\ Hasil Penelitian}

Sampel dalam penelitian ini adalah 88 perusahaan manufaktur yang terdaftar di Bursa 
Efek Indonesia, dengan tahun pengamatan selama tiga tahun (2013-2015) maka total sampel penelitian adalah 264 sampel. Data yang digunakan dalam penelitian ini adalah data sekunder, yaitu annual report (laporan tahunan) dan laporan keuangan yang tersedia kepada publik di laman Indonesia Stock Exchange (IDX) serta data tanggal penyampaian laporan keuangan perusahaan yang didapatkan secara berbayar di The Indonesia Capital Market Institute (TICMI).

\section{Analisis Deskriptif}

Statistik deskriptif yang digunakan dalam penelitian dapat dilihat pada tabel dibawah ini:

Tabel 1.2

Statistik Deskriptif Penelitian

\begin{tabular}{|l|l|l|l|l|l|}
\hline & N & Minimum & Maximum & Mean & Std. Deviation \\
\hline TL & 264 & .00 & 1.00 & .7424 & .43813 \\
ROA & 264 & -20.80 & 52.94 & 5.5502 & 10.03461 \\
CR & 264 & .13 & 13.35 & 2.2744 & 1.88659 \\
DER & 264 & -9.44 & 19.60 & 1.4942 & 2.85388 \\
OUTCON & 264 & 2.43 & 98.41 & 51.1556 & 24.26070 \\
Valid N (listwise) & 264 & & & & \\
\hline
\end{tabular}

Sumber: Data diolah (2017)

Statistik deskriptif memberikan gambaran mengenai karakteristik variabel-variabel penelitian yang diamati. model dapat diterima karena cocok dengan data observasi (model fit dengan data).

\section{Hasil Pengujian Multivariat}

\section{Menilai Model Fit dan Keseluruhan Model}

(Overall Model Fit)

Langkah pertama dalam menilai keseluruhan model (Overall Model Fit) dengan memperhatikan angka -2 Log Likehood (LL), apabila terjadi penurunan dalam angka -2 Log Likehood maka

\section{Tabel 1.3}

\section{Uji -2 Log Likehood}

Iteration History ${ }^{a, \mathrm{~b}, \mathrm{c}}$

\begin{tabular}{|ll|l|l|}
\hline & & Coefficients \\
\cline { 4 - 4 } Iteration & & -2 Log likelihood & Constant \\
\hline Step 0 & 1 & 301.632 & .970 \\
& 2 & 301.227 & 1.057 \\
& 3 & 301.227 & 1.059 \\
& 4 & 301.227 & 1.059 \\
\hline
\end{tabular}

a. Constant is included in the model.

b. Initial -2 Log Likelihood: 301.227

c. Estimation terminated at iteration number 4 because parameter estimates changed by less than .001 .

Sumber: Data diolah (2017) 
Tabel 1.4

-2 Log Likehood Block-1

Iteration History ${ }^{a, b, c, d}$

\begin{tabular}{|c|c|c|c|c|c|c|}
\hline & & \multicolumn{5}{|c|}{ Coefficients } \\
\cline { 3 - 7 } Iteration & \multirow{2}{*}{-2 Log likelihood } & Constant & ROA & CR & DER & OUTCON \\
\hline Step 1 1 & 289.989 & .448 & .023 & -.065 & .009 & .010 \\
& 287.192 & .364 & .041 & -.094 & .009 & .014 \\
3 & 287.096 & .343 & .046 & -.101 & .008 & .015 \\
4 & 287.096 & .342 & .046 & -.101 & .008 & .015 \\
\hline
\end{tabular}

Sumber: Data diolah (2017)

Dengan memperhatikan Tabel 1.3 diketahui angka -2 Log Likehood pada awal (block number $=$ 0) angka -2 LL adalah 301,227 sedangkan pada block number $=1$ di Tabel 1.4 turun menjadi 287,096 dengan angka penuruan yang terjadi sebesar 14,131. Penurunan log likehood dari 301,227 menjadi 287,096 mengindikasikan bahwa model fit dengan data karena cocok dengan data obeservasinya.

\section{Menilai Kelayakan Model Regresi (Hosmer and Lemeshow Goodness of Fit Test)}

Analisis kedua yang dilakukan adalah menilai kelayakan model regresi dengan memperhatikan nilai goodness of fit test yang diukur dengan nilai Chi-square pada bagian bawah uji Hosmer and Lemeshow. Uji Hosmer and Lemeshow digunakan untuk menguji hipotesis nol.

\section{Tabel 1.5}

Uji Hosmer and Lemeshow Goodness of Fit Test

Hosmer and Lemeshow Test

\begin{tabular}{|l|l|l|l|}
\hline Step & Chi-square & df & Sig. \\
\hline 1 & 13.488 & 8 & .096 \\
\hline
\end{tabular}

Sumber: Data diolah (2017)

Hasil pengujian Hosmer and Lemeshow menunjukkan nilai Chi-square sebesar 13,488 dengan probabilitas signifikansi menunjukkan angka 0,096. Nilai signifikansi diperoleh lebih besar dari 0,05 sehingga hipotesis bahwa variabel independen secara bersama-sama mempengaruhi variabel dependen dapat diterima.

\section{Koefisien Determinasi $\left(\mathbf{R}^{\mathbf{2}}\right)$}

NagelKerke's $R$ Square, nilai $R$ Square $\left(\mathrm{R}^{2}\right)$ menunjukkan seberapa berpengaruh variabel independen yang diteliti terhadap variabel dependen. Nilai $R^{2}$ terletak dalam interval $0 \leq R^{2} \leq 1$, apabila $\mathrm{R}^{2}$ semakin mendekati 1 maka semakin besar proporsi sumbangan variabel independen dan sebaliknya. Jika nilai R2 tidak mencapai $100 \%$, maka sisanya dipengaruhi variabel lain diluar model.

\section{Tabel 1.6}

Analisis NagelKarke's R Square Model Summary

\begin{tabular}{|l|l|l|l|}
\hline $\begin{array}{l}\text { Ste } \\
\mathrm{p}\end{array}$ & $\begin{array}{l}-2 \quad \text { Log } \\
\text { likelihood }\end{array}$ & $\begin{array}{l}\text { Cox \& Snell } \\
\text { R Square }\end{array}$ & $\begin{array}{l}\text { Nagelkerke } \\
\text { R Square }\end{array}$ \\
\hline 1 & $287.096^{\mathrm{a}}$ & .052 & .077 \\
\hline
\end{tabular}

a. Estimation terminated at iteration number 4 because parameter estimates changed by less than .001 .

Sumber: Data diolah (2017)

Tabel 1.6 menunjukkan nilai NagelKerke's $R$ Square sebesar 0,077. Nilai ini menunjukkan bahwa proporsi sumbangan variabel independen secara bersama-sama adalah sebesar 7,7\%, sedangkan sisanya sebesar 92,3\% dijelaskan oleh variabilitas variabel-variabel lain di luar model penelitian

\section{Uji Hipotesis}

Untuk menguji pengaruh profitabilitas, likuiditas, financial leverage dan struktur kepemilikan terhadap ketepatan waktu pelaporan keuangan dilakukan dengan menggunakan uji analisis regresi logistik. 
Tabel 1.7

Ringkasan Hasil Analisis Regresi Logistik

Variables in the Equation

\begin{tabular}{|ll|l|l|l|l|l|l|l|l|}
\hline & & & & \multirow{2}{*}{} & & \multicolumn{2}{|c|}{ 95\% C.I.for EXP(B) } \\
\cline { 7 - 9 } & & B & S.E. & Wald & df & Sig. & Exp(B) & Lower & Upper \\
\hline Step 1 ${ }^{\mathrm{a}}$ & ROA & .046 & .020 & 5.078 & 1 & .024 & 1.047 & 1.006 & 1.090 \\
& CR & -.101 & .077 & 1.736 & 1 & .188 & .904 & .778 & 1.050 \\
DER & .008 & .053 & .023 & 1 & .880 & 1.008 & .909 & 1.117 \\
OUTCON & .015 & .006 & 5.640 & 1 & .018 & 1.015 & 1.003 & 1.028 \\
Constant & .342 & .373 & .840 & 1 & .359 & 1.407 & & \\
\hline
\end{tabular}

Sumber: Data diolah (2017)

Dari pengujian dengan regresi logistik diatas maka diperoleh persamaan regresi logistik sebagai berikut:

$$
\begin{gathered}
\ln (\mathrm{TL} / 1-\mathrm{TL})=0,342+0,046 \text { ROA }-1,01 \mathrm{CR}+ \\
0,008 \text { DER }+0,15 \text { OUTCON }+\varepsilon
\end{gathered}
$$

ROA memiliki nilai signifikansi sebesar 0,024, CR memiliki nilai signifikansi sebesar 0,188 , DER memiliki nilai signifikansi sebesar 0,880, OUTCON memiliki nilai signifikansi sebesar 0,018. Hasil ini menunjukkan bahwa variabel profitabilitas dan struktur kepemilikan mempengaruhi ketepatan waktu pelaporan keuangan pada tingkat $5 \% \quad(0,05)$, sedangkan variabel likuiditas dan leverage mempengaruhi ketepatan waktu pelaporan keuangan pada tingkatan lebih dari $10 \%(0,10)$.

\section{Pembahasan}

Pengaruh Profitabilitas, Likuiditas, Financial Leverage, dan Struktur Kepemilikan Terhadap Ketepatan Waktu Pelaporan Keuangan Secara Bersama-sama

Pengaruh profitabilitas, likuiditas, financial leverage, dan struktur kepemilikan secara bersamasama berpengaruh terhadap ketepatan waktu pelaporan keuangan yang ditunjukkan oleh nilai koefisien logit yang tidak sama dengan nol.

Tabel 1.8

Hasil Uji Koefisien Regresi Simultan

Omnibus Tests of Model Coefficients

\begin{tabular}{|ll|c|c|c|}
\hline & & Chi-square & df & Sig. \\
\hline Step & Step & 14.131 & 4 & .007 \\
& Block & 14.131 & 4 & .007 \\
& Model & 14.131 & 4 & .007 \\
\hline
\end{tabular}

Sumber: Data diolah (2017)

Hasil uji simultan dengan metode Omnibus Tests of Model Coefficients menunjukkan nilai Chisquare 14,131 dengan tingkat signifikansi $<0,05$ $(\mathrm{p}=0,000)$ dengan tingkat probabilitas sebesar 0,007. Tingkat probabilitas sebesar 0,007 menunjukkan bahwa adanya pengaruh secara simultan pada variabel profitabilitas, likuiditas, leverage, dan struktur kepemilikan terhadap ketepatan waktu pelaporan keuangan sehingga hipotesis bahwa variabel profitabilitas, likuiditas, leverage, dan strukur kepemilikan secara bersamasama mempengaruhi ketepatan waktu pelaporan keuangan diterima.

\section{Pengaruh Profitabilitas Terhadap Ketepatan Waktu Pelaporan Keuangan}

Profitabilitas yang diukur dengan ROA memiliki nilai koefisien sebesar 0,046 pada degree of freedom 1 dan nilai wald 5,078 dengan tingkat signifikansi sebesar 0,024 ( $\mathrm{P}$ value $<0,05)$. Dapat 
disimpulkan bahwa variabel profitabilitas yang berpengaruh secara signifikan terhadap ketepatan waktu pelaporan keuangan. Hal ini membuktikan bahwa hipotesis profitabilitas mempengaruhi ketepatan waktu pelaporan keuangan diterima. Profitabilitas yang diperlihatkan perusahaan melalui nilai ROA dalam laporan keuangan berpengaruh secara signifikan terhadap ketepatan waktu perusahaan dalam menyampaikan laporan keuangan.

\section{Pengaruh Likuiditas Terhadap Ketepatan Waktu Pelaporan Keuangan}

CR yang dipakai untuk mengukur likuiditas memiliki nilai koefisien sebesar -0,101 pada degree of freedom 1 dan nilai wald 1,736 dengan tingkat signifikansi sebesar 0,188 ( $\mathrm{P}$ value $>0,05$ ). Dapat disimpulkan bahwa variabel likuiditas yang diproksikan dengan $\mathrm{CR}$ secara signifikan tidak berpengaruh terhadap ketepatan waktu pelaporan keuangan sehingga hipotesis likuiditas mempengaruhi ketepatan waktu pelaporan keuangan ditolak. Hal ini membuktikan bahwa ketepatan waktu pelaporan keuangan tidak ditentukan oleh besar kecilnya tingkat likuiditas perusahaan.

\section{Pengaruh Financial Leverage Terhadap Ketepatan Waktu Pelaporan Keuangan}

Variabel leverage yang diproksikan dengan Debt to Equity Ratio (DER) memiliki nilai koefisien sebesar 0,008 pada degree of freedom 1 dan nilai wald 0,023 dengan tingkat signifikansi sebesar 0,880 (P value>0,05). Dapat disimpulkan bahwa variabel leverage yang diproksikan dengan DER secara signifikan tidak berpengaruh terhadap ketepatan waktu pelaporan keuangan sehingga hipotesis tingkat leverage mempengaruhi ketepatan waktu pelaporan keuangan ditolak.

\section{Pengaruh Struktur Kepemilikan Terhadap Ketepatan Waktu Pelaporan Keuangan}

Hasil pengujian hipotesis menunjukkan bahwa struktur kepemilikan yang diproksikan dengan OUTCON memiliki nilai koefisien sebesar 0,015 pada degree of freedom 1 dan nilai wald 5,640 dengan tingkat signifikansi sebesar 0,018 ( $\mathrm{P}$ value $<0,05)$. Dapat disimpulkan bahwa variabel struktur kepemilikan yang diproksikan dengan OUTCON secara signifikan berpengaruh signifikan terhadap ketepatan waktu pelaporan keuangan, maka hipotesis struktur kepemilikan yang diproksi kepemilikan pihak luar mempengaruhi ketepatan waktu pelaporan keuangan diterima.

\section{KESIMPULAN DAN SARAN}

\section{Kesimpulan}

1) Profitabilitas, likuiditas, financial leverage dan struktur kepemilikan berpengaruh secara bersama-sama terhadap ketepatan waktu pelaporan keuangan periode 2013-2015. Hal ini menunjukkan bahwa ketepatan waktu pelaporan keuangan dapat diprediksikan dengan menggunakan keempat variabel independen dalam penelitian ini.

2) Profitabilitas berpengaruh secara parsial terhadap ketepatan waktu pelaporan keuangan pada perusahaan manufaktur periode 20132015. Hal ini menunjukkan bahwa tingkat ROA yang tinggi berisi berita baik, di mana pengumuman laba yang berisi berita baik cenderung untuk dipercepat.

3) Likuiditas tidak berpengaruh secara parsial terhadap ketepatan waktu pelaporan keuangan pada perusahaan manufaktur periode 20132015. Dapat disimpulkan bahwa ketepatan waktu pelaporan keuangan tidak ditentukan oleh besar kecilnya tingkat likuiditas perusahaan karena beberapa perusahaan yang memiliki rasio jauh lebih rendah dari nilai rata-rata rasio likuiditas perusahaan lainnya justru tepat waktu dalam penyampaian laporan keuangannya.

4) Financial leverage tidak berpengaruh secara parsial terhadap ketepatan waktu pelaporan keuangan pada perusahaan manufaktur periode 2013-2015. Hal tersebut menunjukkan bahwa perusahaan dapat menyelesaikan permasalahan hutang melalui proses restrukturisasi hutang. Dalam kondisi perekonomian perusahaan saat ini masalah hutang dianggap biasa dan bukan permasalahan yang luar biasa bagi perusahaan selama masih ada kemungkinan penyelesaiannya.

5) Struktur kepemilikan berpengaruh secara parsial terhadap ketepatan waktu pelaporan keuangan pada perusahaan manufaktur periode 
2013-2015. Hal tersebut menunjukkan bahwa kepemilikan perusahaan oleh pihak luar memiliki kekuatan besar dalam mempengaruhi perusahaan agar berjalan secara maksimal. Tekanan oleh pihak luar akan membuat perusahaan menyampaikan laporan keuangannya secara tepat waktu.

\section{Saran}

1) Penelitian selanjutnya disarankan agar menggunakan periode pengamatan lebih terbaru, sehingga hasil yang didapatkan lebih menggambarkan kondisi sesungguhnya.

2) Penelitian selanjutnya sebaiknya menggunakan rentang waktu yang lebih panjang untuk memberikan hasil yang lebih valid.

3) Penelitian selanjutnya sebaiknya melakukan penambahan variabel lainnya yang berkaitan dengan pengolaan utang, seperti solvabilitas dan leverage dengan proksi gearing ratio.

1. Variabel lainnya yang menarik untuk dilihat pengaruhnya terhadap ketepatan waktu pelaporan keuangan meliputi ukuran perusahaan, pergantian auditor publik, dan item-item luar biasa.

\section{Daftar Pustaka}

Almilia, Luciana Spica dan Lucas Setiady. 2006. Faktor-faktor yang Mempengaruhi Penyelesaian dan Penyajian Laporan Keuangan pada Perusahaan yang Terdaftar di BEJ. Seminar Nasional Good Corporate Governance. Jakarta.

Baridwan, Zaki. 2007. Intermediate Accounting. Edisi 8. Yogyakarta: BPFE

Basuony, Mohamed A.K. and Ehab K.A. 2016. Board characteristics, ownership structure and audit report lag in the Middle East. International Journal of Corporate Governance. Vol. 7, No. 2:180-205.

Brigham, Eugene F. dan Joel F. Houston. 2006. Dasar-dasar Manajemen Keuangan Buku 1. Edisi 10. Jakarta: Salemba Empat.

Carslaw, Charles A. dan Steven E. Kaplan. 1991. An Examination of Audit Delay: Further Evidence from New Zealand. Accounting and Business Research.Vol.22, No.85:21-32.
Dwiyanti, 2010. Analisis Faktor-faktor Yang Mempengaruhi Ketepatan Waktu Pelaporan Keuangan Pada Perusahaan Manufaktur Yang Terdaftar di Bursa Efek Indonesia. Skripsi tidak dipublikasikan. Semarang: Universitas Dipenogoro.

Dyer, James C. dan Arthur J. McHugh. 1975. The Timeliness of The Australian Annual Report. Journal of Accounting Research. Vol.13, No.2:204-219.

Fitri, Fauziah Aida dan Nazira. 2009. Analisis Ketepatan Waktu Penyampaian Laporan Keuangan Kepada Publik: Studi Empiris Pada Perusahaan Manufaktur Yang Terdaftar di BEI. Jurnal Telaah \& Riset Asuransi. Vol.2, No.2:198-214.

Ghozali, Imam. 2013. Aplikasi Analisis Multivariat dengan Program IBM SPSS 21. Edisi 7. Yogyakarta: Badan Penerbit BPFE.

Givoly, Dan dan Dan Palmon. 1982. Timeliness of Annual Earnings Announcements: Some Empirical Evidence. The Accounting Review. Vol.57, No.3:486-508.

Hanafi, Mamduh. 2000. Analisis Laporan Keuangan. Edisi Revisi. Yogyakarta: Unit Penerbit dan Percetakan AMP-YKPN.

Hastutik, Suci. 2015. Pengaruh Profitabilitas, Likuiditas, Struktur Kepemilikan, Ukuran Perusahaan, dan Opini Audit Terhadap Ketepatan Waktu Pelaporan Keuangan Perusahaan. Jurnal Akuntansi dan Sistem Teknologi Informasi. Vol.11. Edisi Khusus:102-111

Hilmi, Utari dan Syaiful Ali. 2008. Analisis Faktor Yang Mempengaruhi Ketepatan Waktu Penyampaian Laporan Keuangan (Studi Empiris pada Perusahaan-perusahaan Yang Terdaftar di BEJ Periode 20014-2006). Simposium Nasional Akuntansi XI.

Ikatan Akuntan Indonesia (IAI). 2014. Standar Akuntansi Keuangan Per Efektif 1 Januari 2015. Jakarta: Ikatan Akuntan Indonesia.

Jensen, M. dan W. Meckling. 2005. Theory of The Firm: Managerial Behavior, Agency Costs, and Ownership Structure. Journal of Financial Economics. Vol 3:305-360

Kadir, Abdul. 2008. Faktor-Faktor Yang Berpengaruh Terhadap Ketepatan Waktu Pelaporan 
Keuangan Studi Empiris Pada Perusahaan Manufaktur Di Bursa Efek Jakarta. Jurnal Manajemen dan Akuntansi (JUMA). Vol.12, No.1:1-12

Khasharmeh, Hussein Ali and Khaled Aljifri. 2010. The Timeliness Of Annual Reports In Bahrain And The United Arab Emirates: An Empirical Comparative Study. The International Journal of Business and Finance Research. Vol. 4, No.1:51-71.

Mufqi, Urvan Maulana. 2015. Pengaruh Debt to Equity Ratio, Profitabilitas, Kepemilikan Pihak Luar, Kualitas Auditor, dan Ukuran Perusahaan Terhadap Ketepatan Waktu Pelaporan Keuangan. Jurnal Online Mahasiswa Fakultas Ekonomi Universitas Riau. Vol.2, No.2.

Na'im, Ainun. 1998. Timeliness of Annual Financial Statement Submission: A Preliminary Empirical Evidence from Indonesia. Asian Academy of Management Journal. Vol.5, No.2.

Nasution, Khiyanda Alfian. 2013. Pengaruh Likuiditas, Ukuran Perusahaan, dan Profitabilitas Terhadap Ketepatan Waktu Dalam Pelaporan Keuangan. Jurnal Akuntansi. Vol.1, No.3.

Penman, Stephen H. dan Anne E. Chambers. 1984. Timeliness of Reporting and The Stock Price Reaction to Earnings Announcements. Journal of Accounting Reasearch. Vol.22, No.1:21-47.

Respati, Novita WeningTyas. 2004. Faktor-faktor yang Berpengaruh Terhadap Ketepatan Waktu Pelaporan Keuangan: Studi Empiris di Bursa Efek Jakarta. Jurnal Maksi. Vol 4:67-81

Saleh, R. dan Susilowati. 2004. Studi Empiris Ketepatan Waktu Pelaporan Keuangan Perusahaan Manufaktur di Bursa Efek Jakarta. Jurnal Bisnis Strategi. Vol.13:67-80

Saleh, Saddam. 2013. Pengaruh Profitabilitas, Solvabilitas, Size Perusahaan, dan Ukuran KAP Terhadap Ketepatan Waktu Penyampaian Laporan Keuangan. Skripsi Tidak Dipublikasikan. Banda Aceh: Universitas Syiah Kuala.

Wirakusuma, Made Gede. 2004. "Faktor-Faktor Yang Mempengaruhi Rentang Waktu Penyajian Laporan Keuangan ke Publik (Studi Empiris Mengenai Keberadaan Divisi Internal Audit pada Perusahaan-Perusahaan Yang Terdaftar di
Bursa Efek Jakarta)". Simposium Nasional Akuntansi VII. (Desember) : pp 1202.1222. http://www.idx.co.id. Diakses 28 Desember 2016. http://www.ticmi.co.id. Diakses 13 Februari 2017. 